\title{
Insight \\ Developing Detailed Foresight Narratives: a Participatory Technique from the Mekong Region
}

\author{
$\underline{\text { Tira Foran }}^{1}, \underline{\text { John Ward }}^{1}, \underline{\text { Eric J. Kemp-Benedict }}^{2}$ and Alex Smajgl $^{l}$
}

\begin{abstract}
Narratives that explore uncertain events are central to a variety of future-oriented approaches ranging from planning to community visioning. Techniques to create interesting narratives, however, have been overlooked in the peer-reviewed environmental foresight literature. We describe a participatory, multidimensional, pragmatic technique to generate qualitative foresight ("scenario") narratives. We applied this technique in the Mekong region of Southeast Asia during 11 workshops conducted in 5 countries and 1 regional setting. To improve consideration of systemic connections, narratives were shared between the six settings, allowing participants to understanding cross-scale enablers and inhibitors of desired development outcomes. A second innovative feature is elaboration of character-oriented narratives. We discuss how the technique responds to ongoing methodological challenges of critical inquiry, policy salience, and agency.
\end{abstract}

Key Words: Asia; Mekong; methodology; narrative; participation; scenario

\section{INTRODUCTION}

Scenario-building approaches aim to generate insight about different ways future worlds might unfold. They serve objectives ranging from planning-oriented decision support, to imaginative exploration of social-ecological change (van Notten et al. 2003). Proponents argue that such foresight facilitates policy actor learning, with the potential for new understandings, connections, and policy narratives (Da Costa et al. 2008, Foran and Lebel 2012). Scenario building can also support and embed public participation in policy making and improve rigor of decision making (Chermack 2004, Patel et al. 2007, Da Costa et al. 2008, Lebel and Bennett 2008, Foran and Lebel 2012).

We describe a technique that allows detailed, multidimensional futures narratives to be created in a participatory manner. Scenario building applications typically involve the development of coherent, plausible, imagined sequences of events that express alternative futures. Although such event sequences could be represented in other media such as models, graphic images, and gaming (Vervoort et al. 2012a), scenario development ultimately demands some degree of narration, if only that required to translate and summarize meanings created in other media. Not surprisingly, scenario methodology makes recurrent use of qualitative, ordinary language storylines, often in combination with quantitative models (Rothman et al. 2007, Alcamo 2008).

Excellent guidance on scenario methodology and techniques (van Asselt and Rijkens-Klomp 2002, Evans et al. 2006, Jäger et al. 2007, Henrichs et al. 2010) deserves to be augmented. Evans et al. (2006) provide detailed, highly practical guidance on participatory storyline development. However, beyond their suggestion that participants present their work to, and train, higher level authorities, they do not discuss how to link scenario activities across settings or scales to further stimulate learning. Henrichs et al. (2010:179) provide comprehensive, step-by-step advice, and discuss the importance of considering multiple geographic scales, but explicitly acknowledge that they do not "address in any detail the process and related (facilitation) techniques that might be used to arrive at the respective outcomes," referring the reader instead to trained facilitators. Professional consultancies have such facilitation expertise but not necessarily incentive to disseminate their techniques, and few descriptions of scenario narrative elaboration technique exist outside of the business literature.

Commenting on environmental scenarios, Rounsevell and Metzger (2010:609) state that "explicit descriptions of the methods are surprisingly rare in the scientific literature." Evidence of methodological weakness also comes from Wangel (2011), who found that out of 17 scenario studies reviewed, only 8 included narrative descriptions of how and by whom change occurs. Of those 8 , only 4 studies explored agents and agency in an explicit and open way, the rest viewed agents of change as determined in advance, as an input to the scenario activity (Wangel 2011). Although the environmental literature has somewhat overlooked the question of how to create compelling storylines, discussion around methodology has touched on other relevant issues. For example:

- Critical and systematic inquiry: When exploring futures that may be influenced by complex, cross-dimension dynamics, how can scenarios go beyond outcomes influenced by their developers' beliefs and worldviews, which may be too restrictive or conventional? (cf. Metzger et al. 2010, Termeer et al. 2010, Vervoort et al. 2012b);

- Policy salience: How can scenario approaches engage today's policy makers in discussion around challenging, uncertain, controversial future developments and 
response strategies? (Patel et al. 2007, Volkery et al. 2008, SEI and CIFOR 2009, Henrichs et al. 2010);

- Endogenous development: In applications exploring "local" futures, given the power of higher order forces such as national policy and globalization, how can scenarios credibly express agency and endogenous development? (Özkaynak and Rodríguez-Labajos 2010, Wangel 2011).

None of the above issues has been resolved with respect to which design choices or techniques are methodologically superior. Diversity of scenario objectives prevents resolution. Meanwhile, we observe calls for applications to explore more than one dimension of society or level of governance, as well as remain highly participatory, inviting participants to coproduce knowledge and policy options (Lebel 2006, Patel et al. 2007, Volkery et al. 2008, Foran and Lebel 2012). Indeed, the benchmark for sophistication in foresight or integrated assessment design appears to have evolved to one where designers now propose and attempt participatory work that crosses disciplinary, geographic, and social scales, in such a way that attracts the interest of policy makers (Kok et al. 2007, Henrichs et al. 2010). Clearly, such work faces nontrivial challenges, for instance how to include then transcend participant understandings of what issues (dimensions) matter most at what levels.

Responding to such methodological and practical challenges, in this paper we describe a technique to generate qualitative storylines that are participatory, multidimensional, and pragmatic. In so doing we seek to increase appreciation for the capacity of detailed qualitative narrative as a basis to explore the future. We applied this technique in developing mainland Southeast Asia during 11 workshops conducted in 2011 in 5 subnational settings, plus 1 supra-national setting.

\section{Context and motivation}

\section{Mekong context}

A characterization of today's Mekong region might begin with its dynamism (Ward et al. 2012). With a growing population of 271 million, it has a youthful and expanding workforce, with significant movement out of smallholder agriculture, although most people still live in rural area and are involved in agriculture. The region is economically and politically diverse: there are three so-called least-developed economies (Cambodia, Lao People's Democratic Republic, and Myanmar) and three larger economies (Thailand, Viet Nam, and Yunnan Province of China). The "Greater Mekong Subregion," a regional cooperation program, also includes China's Guangxi Zhang region.

The region is ambitious in terms of popular aspirations as well as aspirations of leaders and policy makers to expand trade, mining, manufacturing, transport, tourism, and industry.
Notwithstanding the 2008 global financial crisis, some observers project the Mekong region to grow rapidly: GDP growth rates for 2010-2017 range from 5-9\% per annum (IMF 2012). The region is, however, constrained by a number of higher level forces. These pertain to its competitive advantage as a purveyor of food, tourist destinations, textiles and apparel, and other manufactured goods to the global economy, but also include drivers such as climate change and the ongoing stream of social responses to those changes.

Social diversity and dynamism, economic ambition, and the inevitably constrained nature of the region make for complexity. Important examples of complexity include "local" development decisions with the potential to create "regional" impacts, for example, a decision to proceed with one or more large hydropower dams on the mainstream Mekong might trigger regional-scale freshwater fisheries declines (ICEM 2010, Costanza et al. 2011). Investment in irrigation infrastructure to alleviate local poverty might trigger in-migration, exacerbating poverty.

\section{Research design}

We designed the Exploring Mekong Region Futures project to explore the following questions: Does exposure to increased understanding of linkages between food, water, energy, and poverty lead to changes in decision makers' causal beliefs, beliefs about how to achieve desired development outcomes? Does such exposure lead to changes in visions, i.e., expressions of which outcomes are desired? The project ran from 20092013 in six Mekong settings: Yunnan PRC, Lao PDR, northeast Thailand, Cambodia, Vietnam, and a regional setting. Figure 1 provides a conceptual framework, contrasting the real world of development decision making against the science-mediated learning space of the project.

We understand policy making to be influenced by institutions, material interests, and discourse (Lichbach and Zuckerman 1997, John 1998). Discourse includes both normative visions, i.e., about the goals of development, and causal beliefs. Building on previous work that explored the political ecology of decision making (Foran 2006, Lebel et al. 2007, Molle et al. 2009), the project took a particular set of water-related development trends and possible "decisions" as its starting point. Specific development decisions were nominated by research partners because of their hypothesized ability to impact on poverty and ecosystems at regional as well subregional scales (Fig. 1, activity I). The nominated set consisted of: expansion of upland rubber cultivation driven by market incentives; a series of 12 hydropower dams proposed for the lower mainstream Mekong; water resources development for irrigation in northeast Thailand, as well as for the Vientiane plain of Lao PDR; adaptation in the Vietnamese Mekong delta in response to sea level rise, drought, and upstream dams and irrigation (Smajgl et al. 2011). 
Fig. 1. Design of the Exploring Mekong Region Futures project. Note: prevailing discourses (left hand side) influence participant visions and beliefs; connections not depicted.

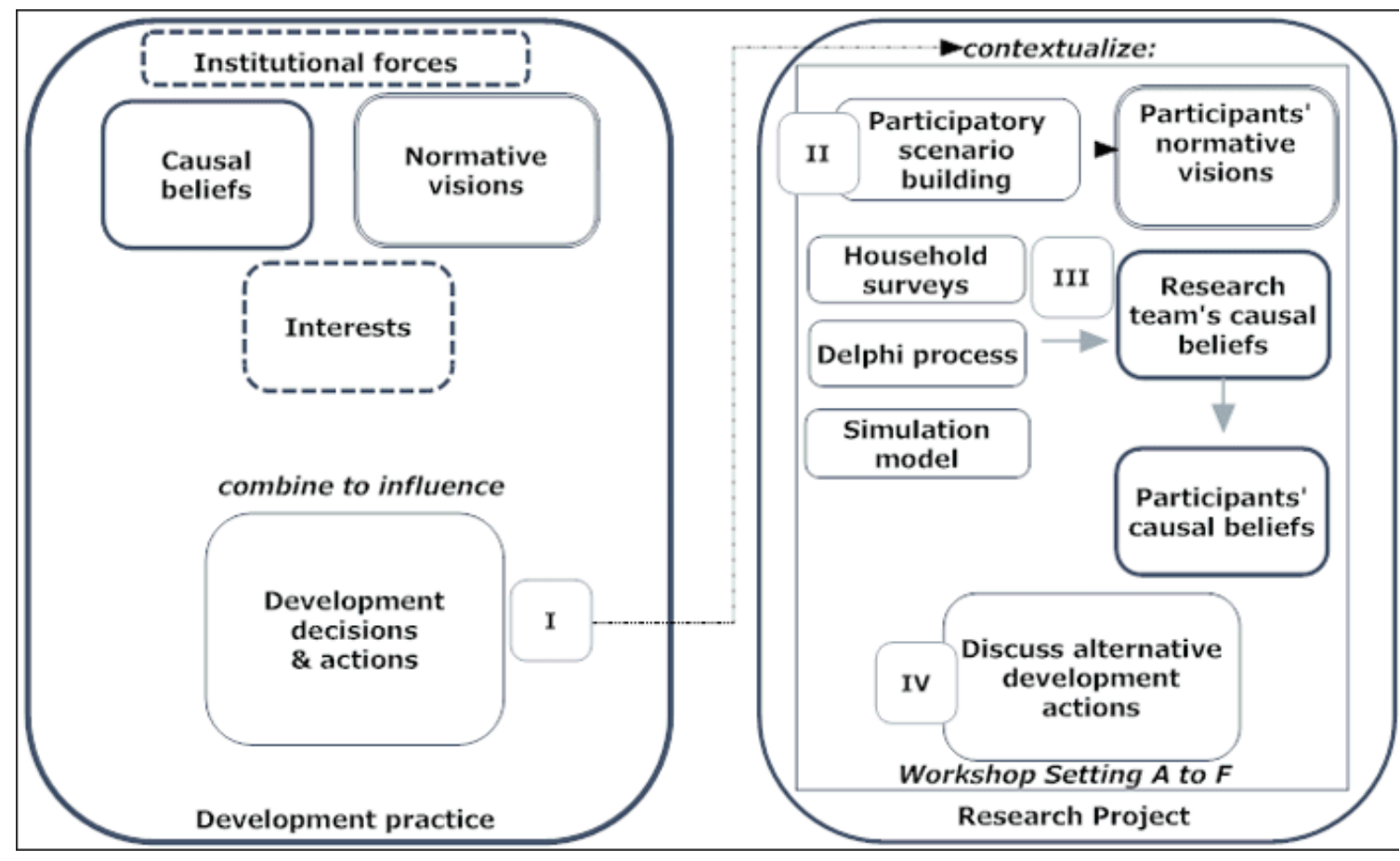

In each setting we invited a set of participants, primarily midlevel officers of national state agencies, to engage in a learning process that began with an exploration of development visions, that is, specific development objectives (Fig. 1, activity II; the focus of this article). We defined a vision as a set of desired and undesired events discernible and embedded in a participant-created, exploratory scenario narrative. Exploratory scenarios (cf. van Notten et al. 2003) express plausible, emergent consequences of selected driving forces. Participants created such scenarios during a first set of workshops. In a subsequent set of workshops they explicitly reflected on normative aspects of their narratives.

In subsequent workshops (Fig. 1, activity III) we elicited participants' explicit causal beliefs. We did so first by forming causal (scientific) beliefs among the research team, then recording participants' reactions to presentation of those beliefs. Participant reactions consisted of restated or revised causal beliefs as well as normative (attitudinal) statements.

The research team's causal beliefs were formed based on techniques including a desktop-based Delphi process (Smajgl and Ward 2013), household surveys, and an agent-based impact assessment model (cf. Smajgl 2010). The final activity involved facilitating a dialogue about alternative development actions that might appear appropriate in light of any changes that emerged in participants' causal beliefs, attitudes, or over- arching visions (Fig. 1, activity IV). In this article we present the scenario-based techniques we used to derive participants' visions.

\section{DETAILED SCENARIO NARRATIVES: A PARTICIPATORY TECHNIQUE}

The seven-step technique we developed to generate detailed, exploratory scenario narratives (Fig. 2) draws on a process described by the Stockholm Environment Institute and Center for International Forestry Research (SEI and CIFOR 2009). This process is based on an intuitive-logic method developed by Kahn et al. (1967), Schwartz (1991), the Global Scenarios Group (Gallopin et al. 1997), Alcamo (2001), and Jäger et al. (2007).

The first four steps of our technique go from bounding and legitimizing the process to creating a specific scenario framework. Because extensive guidance exists on how to accomplish such tasks (Evans et al. 2006, Jäger et al. 2007, Henrichs et al. 2010), our presentation of steps (1) to (4) is deliberately brief; in steps (5) to (7) we elaborate on what is novel.

\section{(1) Scoping and contextualization}

The process requires preliminary identification of the subject (issue) and defining social, geographic, and temporal dimensions of mutual, negotiated interest to scenario 
Fig. 2. Mekong scenario elaboration technique.

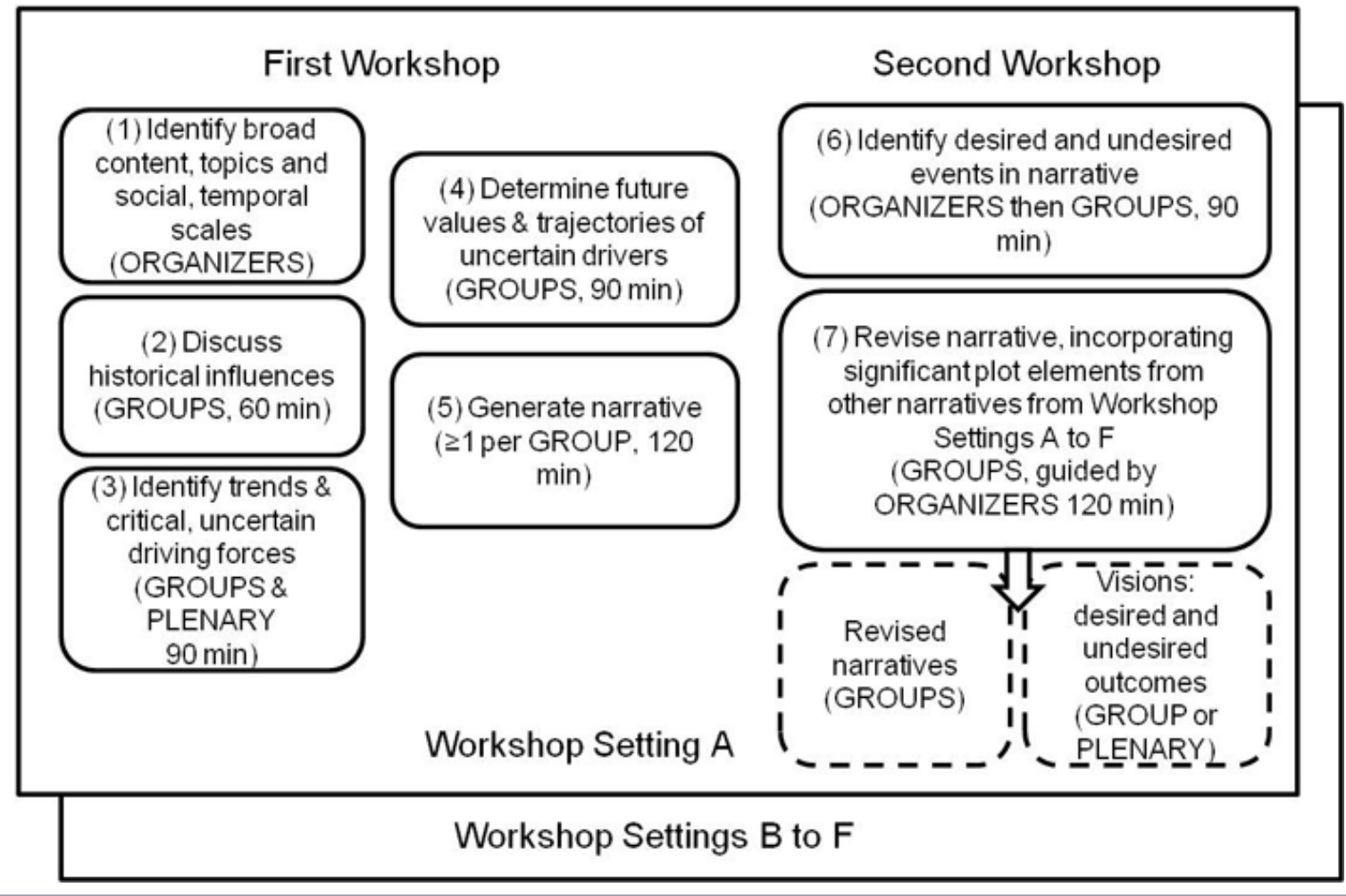

organizers and prospective participants. When the goal of the exercise is to explore the future of a geographic area, which will be influenced by multiple policy issues, subject and temporal scale should not be defined too narrowly. For example, in the Mekong Futures project, participants were invited to explore how interactions between food, water, energy, and poverty might unfold in a particular geographic setting over 50 years.

\section{(2) Discuss historical influences}

This small group step focuses on exploring the question "What forces have made the area or issue what it is today?" Although a scenario exercise aims to explore the future, clarifying the role of social forces and influences that have been important in the past is vital. This step provides a way to move between the essentially arbitrary system boundaries chosen in Step (1) and the future-oriented discussion beginning in Step (3). The step accomplishes additional objectives: it gives participants, indirectly, an introduction to more abstract thinking, discussing a variety of forces (causal processes) acting on the focal subject. Second, participants review the actual historical dynamism of regions. Third, in small group settings, a historical discussion initiates microsocial rapport and subsequent constructive debate. To complete this step, participants nominate key historical influences on the issue or area. Facilitators guide discussion, making use of timelines that might stretch at least as far back in time as the exercise strives to look forward (Fig. 3).

(3) Create initial scenario framework

The purpose of this plenary step is to create an initial scenario framework: a set of important social and ecological driving forces, classified as either trends or critical uncertainties. Driving forces are scale-dependent factors that have an influence on the system and that are usually out of the shortterm control of policy makers. For example, to a national policy maker, international commodity prices are typically a driving force, while import and export taxes are not. To a local policy maker both of these factors may qualify as driving forces, whereas policies set locally are not (SEI and CIFOR 2009). A critical uncertainty is explained to participants as a force with high impact, but with multiple possible future outcomes or trajectories (Jäger et al. 2007). Driving forces can be classified on a two-dimensional array in which the horizontal axis represents perceived uncertainty, and the vertical axis represents perceived importance, in terms of impact on society. This array constitutes the initial structure from which detailed narratives can be subsequently created (Table 1). 
Fig. 3. Example of historical review. Source: After Regional Group 3 in Foran et al. (2013)

\begin{tabular}{|c|c|c|c|c|}
\hline 1990 & 1995 & 2000 & 2005 & 2010 \\
\hline $\begin{array}{l}\text { Peace \& stability } \\
\text { (mostly) }\end{array}$ & $\begin{array}{l}\text { More frequent } \\
\text { droughts }\end{array}$ & \multicolumn{2}{|c|}{$\begin{array}{l}\text { Iraq War }->\text { Oil price impacts -> } \\
\text { diversification strategies }\end{array}$} & $\begin{array}{l}2009 \\
\text { Copenhagen } \\
\text { COP 15 } \\
\text { conference }\end{array}$ \\
\hline $\begin{array}{l}\text { Global and } \\
\text { regional } \\
\text { integration } \\
\text { Cooperation } \\
\text { (ASEAN) and } \\
\text { competition }\end{array}$ & $\begin{array}{l}\text { Cross-boundary } \\
\text { trade: resource } \\
\text { \& energy flows }\end{array}$ & $\begin{array}{l}\text { Climate change } \\
\text { Kyoto protocol } \\
\text { shapes } \\
\text { investment \& } \\
\text { decision making }\end{array}$ & $\begin{array}{l}\text { Decrease in dry } \\
\text { season water in } \\
\text { Mekong Delta } \\
\text { (from upstream } \\
\text { irrigation?) }\end{array}$ & \\
\hline \multicolumn{2}{|c|}{ URBANIZATION, ECONOMIC GRO } & $\begin{array}{l}\text { Dam } \\
\text { construction }\end{array}$ & $\begin{array}{l}\text { 2008: worldwide, } \\
\text {-> } 75 \% \text { by } 2030 ? \\
\text { Better urban ser } \\
\text { Increase in remit } \\
\text { Factory labor } \\
\text { Underemployme } \\
\text { More special eco } \\
\quad \text { cultural chan } \\
\text { Commercial plan } \\
\text { Land conflicts (C } \\
\text { Lao PDR) }\end{array}$ & $\begin{array}{l}\text { ations } \\
\text { ambodia, China, } \\
\text { China - Lao high } \\
\text { speed train } \\
\text { announced }\end{array}$ \\
\hline & $\begin{array}{l}\text { More intensive } \\
\text { rice \& diversified } \\
\text { agriculture }\end{array}$ & $\begin{array}{l}\text { Fast and high } \\
\text { economic } \\
\text { growth }\end{array}$ & $\begin{array}{l}\text { Poverty } \\
\text { decreases from } \\
35 \% \text { to } 27 \%\end{array}$ & \\
\hline & $\begin{array}{l}\text { Increased use of } \\
\text { chemicals } \\
\text { Declining water } \\
\text { quality }\end{array}$ & $\begin{array}{l}\text { Land owners } \\
\text { move out of } \\
\text { agriculture }\end{array}$ & $\begin{array}{l}\text { Increasing } \\
\text { wealth in } \\
\text { Vietnam \& } \\
\text { China }\end{array}$ & $\begin{array}{l}\text { Example for } \\
\text { Laos and } \\
\text { Cambodia? }\end{array}$ \\
\hline $\begin{array}{l}\text { Overfishing \& } \\
\text { deforestation }\end{array}$ & $\begin{array}{l}\text { Loss of rural } \\
\text { farm labor } \\
\text { Social tensions } \\
\text { w/migrant labor }\end{array}$ & $\begin{array}{l}2002 \text { regional } \\
\text { power trade } \\
\text { MOU } \\
2004 \text { Tsunami }\end{array}$ & & 2011 Tsunami \\
\hline
\end{tabular}

In each setting of the Mekong application, small group work was pooled into one joint scenario framework, which resulted in extensive arrays of driving forces (Table 1). Groups occasionally differed about the uncertainty of a given driving force; such differences were later noted in plenary. This step is time consuming because it requires individuals to nominate and justify candidate driving forces, as well as facilitated group discussion about the relative importance and uncertainty of driving forces. However, the purpose is to generate a first- order prioritization of driving forces (Table 1), with an opportunity for further refinement in step (4). It is not necessary to derive a precise ranking.

(4) Create a specific scenario framework

The purpose of this small group step is to create a finite and coherent set of imagined statements about the future, from which a more elaborate narrative can be created. This framework should include trends as well as critical 
Table 1. Example of initial scenario framework. Source: After Xishuangbanna workshop in Foran et al. (2013).

\begin{tabular}{|c|c|}
\hline $\begin{array}{l}\text { Trends } \\
\text { High Impact, Low Uncertainty }\end{array}$ & $\begin{array}{l}\text { Uncertain Drivers } \\
\text { High Impact, High Uncertainty }\end{array}$ \\
\hline Social, Political, Economic & Social, Political, Economic \\
\hline Increasing mobility of population & Demands of outside market for natural resources: land, hydropower, minerals \\
\hline Industrial development & Guiding economic policy \\
\hline Open market and border trade & Local future economic plan \\
\hline Market economy & Globalization and promotion of China's position in the world \\
\hline Tourism development & Investment \\
\hline Economic development models & Changing prices of rubber and tea \\
\hline Regionalization strategy: Yunnan as "Gateway" & Power of outside investors \\
\hline Implementation of environmental protection policy & Changing lifestyles \\
\hline Urbanization & Vocational and higher education \\
\hline Cash crop plantation & Increasing population \\
\hline Human intervention & Government policy \\
\hline Car industry development & Capital flows \\
\hline \multicolumn{2}{|l|}{ Improving infrastructure } \\
\hline Technology development and import & Natural Resources and Land Use \\
\hline Migration & Property rights \\
\hline \multicolumn{2}{|l|}{ Industry needs } \\
\hline Integrated regional economy & Ecosystems \\
\hline Internationalization & Impacts of chemicals used \\
\hline Natural Resources and Land Use & Food \\
\hline Limited land resources & Water resources for agricultural production \\
\hline \multicolumn{2}{|l|}{ Land use intensification } \\
\hline Increasing demand for natural resources & $\begin{array}{l}\text { Energy } \\
\text { Alternative energy: biofuel and other alternative technologies }\end{array}$ \\
\hline \multicolumn{2}{|l|}{ Ecosystems } \\
\hline \multicolumn{2}{|l|}{ Climate change (temperature increasing) } \\
\hline \multicolumn{2}{|l|}{ Environmental protection } \\
\hline \multicolumn{2}{|l|}{ Rain forest protection program in Xishuangbanna } \\
\hline \multicolumn{2}{|l|}{ Food } \\
\hline \multicolumn{2}{|l|}{ Dietary transition: from rice based to diversified diets } \\
\hline Energy & \\
\hline Hydropower development & \\
\hline
\end{tabular}

uncertainties selected on the basis of their interest value to participants. Where the goal is to explore multiple dimensions, participants should be guided to create a specific scenario framework that consists of a topically diverse set of drivers. Table 2 provides one such example. To complete this step, participants choose a subset of uncertain drivers from the initial scenario framework. Participants agree on a value (result) they imagine could be expressed at a particular future date, for all of the chosen drivers. To add realism and complexity, participants can imagine the trajectory between start and end, taking into account interactions between drivers.

\section{(5) Generate first-order narratives}

The purpose of this small group step is to translate dynamic abstract forces in the specific scenario framework into a concrete and more detailed qualitative narrative. A scenario storyline should, by definition, offer answers to questions of agency, how change occurs (process or mechanism) and by whom, questions that are underdeveloped or missing from the specific scenario framework. A compelling storyline will reveal clear, plausible, indicative (illustrative) answers, allowing a fictional but instructive story of the future to unfold.

In settings where participants are new to working with abstract forces and storyline development, we find it useful, furthermore, to generate individual character-oriented stories. Some participants may regard such a task as frivolous, but visualizing individuals, as opposed to only more abstract entities such as nation states, markets and other institutions, or large organizations, challenges story developers to imagine how forces and events in the scenario framework manifest in the lives of individual protagonists. This technique may be particularly convenient when the goal of the scenario activity is to explore the future of a specific area.

A chronological, character-based narrative can incorporate multiple detailed statements, which in turn allow the working 
Table 2. Example of specific scenario framework. Source: After Xishuangbanna Group 2 in Foran et al. (2013).

\begin{tabular}{ll}
\hline \hline Drivers & Imagined Trajectory 2011-2041 \\
\hline $\begin{array}{l}\text { Technology Development (High yield species, } \\
\text { hybrid transgenic varieties, substitutes for rubber) }\end{array}$ & High yield rubber species peak by 2031, then decline (hump-shaped trajectory) \\
$\begin{array}{l}\text { Urbanization } \\
\begin{array}{l}\text { Capital flows (large scale rubber planting, transfer } \\
\text { of land use rights; also emergence of new } \\
\text { industries) }\end{array}\end{array}$ & $\begin{array}{l}\text { Farmland shrinks, urbanization increases, saturates after 2031 } \\
\text { Investment in commercial plantations increases, saturates by 2041 }\end{array}$ \\
& $\begin{array}{l}\text { Increasing cross-border mobility, rapid growth in immigrant population, increase in education and } \\
\text { ecological awareness }\end{array}$ \\
Climate Change & Precipitation declines, evaporation increases, temperature increases \\
\hline
\end{tabular}

of multiple drivers to be explored. The specific choice of an individual protagonist depends on the focus of the exercise, but it is convenient to create a protagonist whose socialeconomic background is modest enough to allow easy audience identification, while allowing this character to plausibly participate in, or initiate events that conform to the logic of the specific scenario framework.

To explore social and environmental futures, useful characters are those whose livelihoods are (i) situated at the interface of the social and the ecological systems, and (ii) insecure, although not so deprived as to rule them out as a change agent altogether. If the focus is on the future of a particular rural area, it may be useful to generate a protagonist who comes from a farming household because agriculture allows discussion of connections between different systems, e.g., food, water and energy, in accessible terms. Similarly, useful archetypes for urban narratives might include informal selfemployed workers, entrepreneurs, or designers.

(5.1) Participants construct a character along with their family background. We found it useful to tell the story from the perspective of a child or adolescent at the very beginning of the narrative.

(5.2) With the support of note-takers, participants take turns telling one or more characters' life stories. We initiated the process by asking each participant, in turn, to verbally improvise the story in short passages comprising several statements, carrying on from the previous participant. As they did this, participants were encouraged to refer continually to the specific scenario framework.

The improvisational story-telling allowed elements from the scenario framework to be selected, converted into a series of imaginative events that unfolded over time, and thus elaborated. Participants were encouraged to bring in all elements of the framework and articulate how each element affects the lives of the characters.

If the specific scenario framework developed in Step (4) contains a mixture of challenge and opportunity, stories guided by it will likewise contain a mixture of events that are more and less favorable to the focal characters and settings. Facilitators should encourage participants to refer to the framework to avoid monotonic narratives. The output of this step can be considered a 'first-order' narrative. In longer workshop settings, more than one first-order narrative can be created per group, if desired.

\section{(6) Recording notable events and dynamics}

This small group step allows organizers and participants to begin reflecting on significant events and dynamics that occur in their first-order narratives. Such events and dynamics are notable in large part because they include normatively desired and undesired changes or outcomes.

(6.1) Prior to a workshop setting, scenario organizers analyze each narrative, identifying and tabulating notable events, classifying them as desirable, undesirable, or ambivalent (see Appendix 1).

(6.2) Using tables of candidate events created in the previous step as aide, or for new participants, as an entry point, participants review their first-order narrative and generate their own table of notable, desired, and undesired events. In the Mekong Futures project, we referred to desired and undesired events as normative visions. The project methodology required that we record such visions; we did so by collecting participant-generated summary tables.

\section{(7) Revise first-order narratives}

The purpose of this small group activity is to improve the coherence, plausibility, complexity, and salience (interestvalue) of narratives to storytellers and stakeholder audiences alike. Participants can enrich draft narratives in several ways. They can add more imaginative detail about what happens to key drivers over time; draw on elements from the original joint scenario framework not yet used; and importantly, revise their narrative after reviewing dynamics and plotlines that appear in stories created by other participants, i.e., other small groups in the same workshop or other groups in 'distant' workshops. The latter category of stories includes those created by participants involved in parallel scenario activities in other settings or at other scales. 
(7.1) Organizers review first-order narratives for common weaknesses such as vagueness, departures from the choices made in the specific scenario framework, lack of temporality, implausible plotlines. Narratives often appear plausible because they reflect dominant causal beliefs. Organizers review first-order narratives for stylized or questionable beliefs, codifying them, as well as drawing authors' attention to them in the form of comments. Stylized beliefs are often those driving favorable outcomes in stories. Important comments are tabulated, using the table of notable events produced in Step 6.1 (Appendix 1).

(7.2) The purpose of this step is to stimulate cross-scale learning. Considering each first-order narrative in turn as the focal narrative, organizers review one or more other stories created during Step 3. Let story A represent an elaboration of specific scenario framework $i$, and stories $\mathrm{B}, \mathrm{C}, \mathrm{D}$ an elaboration of specific scenario frameworks $j, k, l$. Organizers consider events in stories B, C, D. Assuming they occurred, what would be the impact on events in A, the "focal" narrative? Do events in other stories, such as policy initiatives, economic development strategies, or entrepreneurial schemes, enable or inhibit desired events in the focal narrative? By enable, we mean supports desired elements (or opposes undesirable elements) in the focal narrative. Organizers compile lists of candidate enablers and inhibitors (see Appendix 1).

This task could possibly yield a revised story A1 that combines two or more potentially incommensurate scenario frameworks. However, in practice participants avoided producing stories that contradicted the logic of their original scenario framework.

(7.3) Using the table created in the previous step as a guide, participants are asked to read one or more other-group narratives of relevance to the focal narrative, presenting then discussing interesting dynamics in those narratives.

(7.4) Participants take turns to retell the story. As they engage in this second telling of the story participants are encouraged to incorporate plotlines of interest from other stories, new details, and responses to organizers' comments (Fig. 4).

(7.5 Optional) This activity is useful if data about the intensity of preferences is needed. Organizers ask participants to express their preferences for realizing desired events and avoiding undesired events. This can be done using a number of voting techniques.

(7.6) Small groups present outputs to plenary. The product of the above technique should consist of at least two detailed exploratory narratives, i.e., one per breakout group. These are generated from a common (whole-of-workshop) general scenario framework; elaborated into a specific scenario framework at the small group level; and further elaborated in an iterative manner using participatory storytelling techniques. The technique does not require professional writers. When created by policy actors and lay participants, the narratives have obvious normative valence, but the vantage point is exploratory, as opposed to backcasting.

Fig. 4. Combining verbal and written narration: Vietnam Group 2.

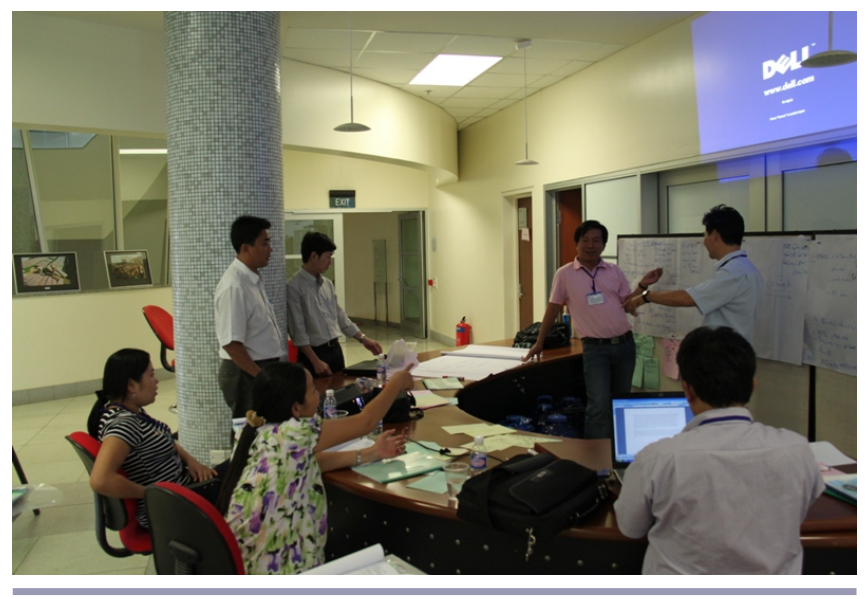

\section{AN APPLICATION IN THE MEKONG REGION}

\section{Participant recruitment and facilitation}

Individuals were selected to join the activities of the Mekong Futures project on the basis of their role as implementers, advisers, or commentators on decisions taken by national or subregional development organizations. In each of five "local" settings, locally-based research partners advised on the participant mix. Participants came predominately from government agencies and from a non-English speaking background. Local workshops were conducted in the local national language, with native speaking facilitators. The region has a paucity of participatory environmental scenario applications (cf. Foran and Lebel 2007, 2012); most participants and facilitators had limited or no exposure prior to being introduced to the technique.

Iterative, cross-scale design

Two rounds of scenario development were conducted in five geographic settings according to the sequence shown in Table 3. In Laos, the sixth setting, logistic constraints prevented implementing the full methodology, which requires a sufficient time interval for organizers to conduct analysis (Step 7.2) to guide participant cross-scale learning. A total of 11 scenario workshops were organized. In some settings, the identities of individual participants varied between workshops.

In each setting, the first workshop completed Steps (1) to (5) above. A second workshop was required to complete Steps (6) and (7). As an input to Step (7), a subset of narratives from other (distant) settings that we assessed as most relevant were 
Table 3. Iterative, cross-scale design of Mekong scenario workshops.

\begin{tabular}{|c|c|c|c|c|}
\hline Process & Area-specific topics & $\begin{array}{l}\text { First-round workshop } \\
\text { (2011) }\end{array}$ & $\begin{array}{c}\text { Second-round } \\
\text { workshop (2011) }\end{array}$ & $\begin{array}{l}\text { Inputs to Second } \\
\text { round } \\
\end{array}$ \\
\hline (A) Northeast Thailand & $\begin{array}{l}\text { Diversification of agriculture, irrigation } \\
\text { development in Huai Sai Baht catchment, } \\
\text { Chi-Mun basin }\end{array}$ & $\begin{array}{c}\text { (A1) } \\
\text { 20-21 January }\end{array}$ & $\begin{array}{c}\text { (A2) } \\
\text { 2-3 June }\end{array}$ & A1-E1 \\
\hline (B) Tonle Sap, Cambodia & $\begin{array}{l}\text { Commercialization of rice farming, } \\
\text { changes to Tonle Sap ecosystem }\end{array}$ & $\begin{array}{c}\text { (B1) } \\
\text { 16-17 March }\end{array}$ & $\begin{array}{c}\text { (B2) } \\
\text { 6-7 July }\end{array}$ & A2; B1-E1 \\
\hline (C) Mekong Delta, Vietnam & $\begin{array}{l}\text { Adapting rice and shrimp to changes in } \\
\text { Mekong Delta (salinity intrusion, upstream } \\
\text { diversions, sea level rise) }\end{array}$ & $\begin{array}{c}(\mathrm{C} 1) \\
\text { 22-23 March }\end{array}$ & $\begin{array}{l}(\mathrm{C} 2) \\
6 \text { August }\end{array}$ & $\mathrm{A} 2-\mathrm{B} 2 ; \mathrm{C} 1-\mathrm{E} 1$ \\
\hline (D) Regional & $\begin{array}{l}\text { Hydropower development, farming, } \\
\text { involuntary migration, new rural } \\
\text { livelihoods }\end{array}$ & $\begin{array}{c}\text { (D1) } \\
\text { 28-29 March }\end{array}$ & $\begin{array}{c}\text { (D2) } \\
\text { 25-26 August }\end{array}$ & $\mathrm{A} 2-\mathrm{C} 2 ; \mathrm{D} 1 ; \mathrm{E} 2$ \\
\hline (E) Xishuangbanna (China) & Future of rubber & $\begin{array}{c}\text { (E1) } \\
\text { 23-24 May }\end{array}$ & $\begin{array}{l}\text { (E2) } \\
18 \text { July }\end{array}$ & A2; B1-E1 \\
\hline (F) Nam Ngum Basin, Laos & $\begin{array}{l}\text { Commercialization of rice farming, } \\
\text { adapting to hydropower expansion }\end{array}$ & $\begin{array}{c}\text { (F1) } \\
22 \text { August }\end{array}$ & $\begin{array}{c}\text { (F2) } \\
23 \text { August }\end{array}$ & $\mathrm{F} 1 ; \mathrm{D} 1 ; \mathrm{A} 2, \mathrm{~B} 2, \mathrm{C} 2, \mathrm{E} 2$ \\
\hline
\end{tabular}

translated into local languages. The product of the secondround workshop consisted of a revised narrative (see Box 1) along with an accompanying statement of desired/undesired future events. A compilation of outputs is available from the authors (Foran et al. 2013).

\section{Stories}

A total of 21 narratives were produced (one revised narrative per participant group), ranging in length from 472 to 1404 words $(\mu=900, \sigma=261)$. Of the 21,17 groups completed the full methodology. On average, narratives produced using our character-driven technique were significantly longer $(0.001<$ $P$, two-sample $t$ test) than participatory rural development scenarios reported by Van Berkel et al. $(2011 ; \mu=348, \sigma=$ 61). Average narrative length increased between first and second round storyline development $\left(\mu_{\text {roundone }}=687 ; \mu_{\text {roundtwo }}\right.$ $=945$ words, $\mathrm{n}=17$ ). Notably, structured turn-taking (Step 5.2) resulted in longer narratives. Groups that took structured turns produced first-order narratives significantly longer ( $0.001<P$, two-sample $t$ test) than those that did not $\left(\mu_{\text {structured }}\right.$ $=965, \sigma_{\text {structured }}=347, \mathrm{n}=10 ; \mu_{\text {unstructured }}=443, \sigma_{\text {unstructured }}=211$, $\mathrm{n}=11)$. Topics common to all workshops included environmental change, rural livelihoods and farming systems, governance responses to social inequality, and enabling institutions at different scales (Table 4).

\section{Cross-scale events}

A preliminary analysis of first- vs. second-order Mekong storylines reveals that 15 of 17 groups that went through the full methodology included "cross-scale events" in their final narrative, i.e., storyline elements that we infer to have crossed from one geographic setting to another, on the basis of specific reading we assigned in Step (7), and/or other explicit geographic identifiers. Of the 17, 12 groups also included cross-scale events in their table of desired and undesired events (Step 6). In revised stories, the most frequently incorporated cross-scale events were: local knowledge and learning networks; commercial-scale organic farming systems; economic opportunities from carbon markets, and eco-tourism (Table 4), all of which were treated as enablers. Revised stories contained one to four cross-scale events (see Box 1).

\section{Storylines}

A preliminary analysis of Mekong storylines revealed that protagonists, $50 \%$ of whom were women, changed locality and livelihood, frequently taking risk voluntarily, as well as experiencing it involuntarily (Foran et al. 2013). A common theme was that well-being will improve if people can stay in rural areas and avoid the instability of work, especially low skilled wage-labor, in cities. Several expressed a vision in which people do well working in family or community enterprises involved in organic farming, aquaculture, carbon forestry, and eco-tourism. Some stories imagined that if environmental governance improves, such enterprises could coexist near heavier industry, providing rural nonfarm employment for farmers displaced because of inability to compete. Many narratives used the life story genre as a vehicle to show how uncertain drivers manifested themselves over time, and to what effect on the lives of focal characters and their families. Stories included multiple setbacks and reversals. They outlined, as opposed to engaged in detailed analysis of, emerging livelihoods or markets. Thus in Xishuangbanna (China) story 2, the protagonist is a rubber farmer who expands his holdings, then after experiencing natural disasters and expropriation, diversifies profitably into ornamental flowers and restoration of rubber plantations (Box 1).

\section{Agency}

The most frequent type of agency was individual: storytellers imagined future worlds in which individuals and their families followed ostensible opportunities created through higher level 
Table 4. Summary of scenario topics and storyline elements. Notes: " $X$ " means item occurs in one or more narratives in given setting. Italicized headings denote themes and bold items refer to traceable cross-scale storyline elements (see text).

\begin{tabular}{|c|c|c|c|c|c|c|}
\hline \multirow[t]{2}{*}{ Topic and Storyline Element } & \multicolumn{6}{|c|}{ Workshop Setting } \\
\hline & $\begin{array}{l}\text { Thailand } \\
\text { (A) }\end{array}$ & $\begin{array}{l}\text { Cambodia } \\
\text { (B) }\end{array}$ & $\begin{array}{l}\text { Vietnam } \\
\text { (C) }\end{array}$ & $\begin{array}{l}\text { Regional } \\
\text { (D) }\end{array}$ & $\begin{array}{l}\text { China } \\
\text { (E) }\end{array}$ & $\begin{array}{l}\text { Lao PDR } \\
\text { (F) }\end{array}$ \\
\hline \multicolumn{7}{|l|}{ Environmental change } \\
\hline Destructive flooding, drought, and/or sea-level rise & & $\mathrm{X}$ & $\mathrm{X}$ & $\mathrm{X}$ & $\mathrm{X}$ & \\
\hline Water pollution & & & $\mathrm{X}$ & $X$ & & $\mathrm{X}$ \\
\hline \multicolumn{7}{|l|}{ Agriculture } \\
\hline \multicolumn{7}{|l|}{ Risk, innovation, adaptation } \\
\hline New rice varieties (salt- or flood-tolerant) & & $\mathrm{X}$ & $\mathrm{X}$ & & & \\
\hline New rubber varieties & & & & & $\mathrm{X}$ & \\
\hline Voluntary certification systems & & & $\mathrm{X}$ & & & \\
\hline Innovations to rice-shrimp model & & & $\mathrm{X}$ & & & \\
\hline Commercial-scale smallholder organic farming & $\mathrm{X}$ & & $\mathrm{X}$ & $\mathrm{X}$ & $\mathrm{X}$ & $\mathrm{X}$ \\
\hline \multicolumn{7}{|l|}{ Diversified farming systems } \\
\hline System of rice intensification & & & & $\mathrm{X}$ & & \\
\hline Agroforestry and carbon forestry & $\mathrm{X}$ & & $\mathrm{X}$ & $\mathrm{X}$ & & \\
\hline Inland capture fisheries decline & $\mathrm{X}$ & $\mathrm{X}$ & & $\mathrm{X}$ & & $\mathrm{X}$ \\
\hline \multicolumn{7}{|l|}{ Socioeconomic differentiation } \\
\hline Exit of noncompetitive farmers & & & $\mathrm{X}$ & & & \\
\hline Increase in land tenure problems & & $\mathrm{X}$ & & & & \\
\hline Monocultures: rubber, sugar cane (ethanol) & $\mathrm{X}$ & & & & $\mathrm{X}$ & \\
\hline \multicolumn{7}{|l|}{ Energy and resources } \\
\hline Regional energy trade; renewable energy target and projects & & & & $\mathrm{X}$ & $\mathrm{X}$ & $\mathrm{X}$ \\
\hline Hydropower: limited large hydropower; lower tariffs in Cambodia & & $\mathrm{X}$ & & $\mathrm{X}$ & & \\
\hline $\begin{array}{l}\text { Participatory planning of power stations; effective involuntary } \\
\text { resettlement; benefit sharing }\end{array}$ & & & & $\mathrm{X}$ & & \\
\hline Coal-fired power with carbon sequestration & & & & $\mathrm{X}$ & & \\
\hline Hydropower-induced erosion and sedimentation & & $\mathrm{X}$ & & & & $\mathrm{X}$ \\
\hline Mining-induced landslides & & & & & $\mathrm{X}$ & \\
\hline \multicolumn{7}{|l|}{ Social inequality and governance } \\
\hline \multicolumn{7}{|l|}{ Accountability, poverty reduction, and education } \\
\hline Civil society movements & & & & $\mathrm{X}$ & & \\
\hline Fair wages for industrial workers and govt officials & & $\mathrm{X}$ & & $\mathrm{X}$ & & \\
\hline Vocational training for displaced farmers & & & $\mathrm{X}$ & & & \\
\hline Corruption and weak environmental enforcement & & $\mathrm{X}$ & & & & \\
\hline \multicolumn{7}{|l|}{ Enabling institutions } \\
\hline Liberalization of trade and labor migration & $\mathrm{X}$ & & & $\mathrm{X}$ & $\mathrm{X}$ & \\
\hline Local knowledge and learning networks & $\mathrm{X}$ & $\mathrm{X}$ & $\mathrm{X}$ & $\mathrm{X}$ & $\mathrm{X}$ & $\mathrm{X}$ \\
\hline Water agreement between Mekong countries & & $\mathrm{X}$ & $\mathrm{X}$ & & & \\
\hline Regional carbon policy: carbon markets & & & & $\mathrm{X}$ & & \\
\hline Social welfare harmonized at regional scale & & & & $\mathrm{X}$ & & \\
\hline Payment for environmental services & & & & $\mathrm{X}$ & $\mathrm{X}$ & \\
\hline Improved rural roads, electricity, irrigation & $\mathrm{X}$ & $\mathrm{X}$ & $\mathrm{X}$ & $\mathrm{X}$ & & \\
\hline \multicolumn{7}{|l|}{ Private enterprise } \\
\hline Eco-tourism and agri-tourism & $\mathrm{X}$ & $\mathrm{X}$ & & $\mathrm{X}$ & $\mathrm{X}$ & $\mathrm{X}$ \\
\hline
\end{tabular}

forces, such as policies establishing payments for environmental services and carbon forestry. Stories featured protagonists who pursued such 'opportunities' early in their careers, as well as those that did so only much later. Protagonists frequently led their community by example. Governments rewarded the talents and abilities of local protagonists with funding support or status recognition (see Box 1). Some stories, however, conveyed a sophisticated sense of how local-scale collective agency requires external resources, individual capacity, and cooperative social relations: 
During the time Nary lived in the city, her village started to change as a result of the attention paid by the government, various organizations, and especially people's participation and awareness of the importance of natural resources on their lives.... $[D]$ irect experience of the difference between abundance and shortage ... encouraged [villagers] to actively participate in the organization of the village to become an eco-tourism village, a solution to make the maintenance of nature coincide with the development of their livelihoods. However, they would also not forget that eco-tourism could grow based on many factors, particularly unity and mutual trust between those living in the community, and a focus on collective interests rather than individual interests, which provided good outcomes over a longer period of time. ... [Nary] educated neighbours in the techniques needed in respect of producing products without the use of chemicals, organizing groups to supply markets and exporting products to the markets. As a result, her family livelihood improved (after Cambodia Group 3, in Foran et al. 2013).

\section{Box 1:}

In the city of Jinghong, on the banks of the Mekong River, lives AMeng, the older of two children. His younger sister works for the Rainforest Protection Foundation ... their father is local Dai, their mother Burmese. Due to his family background, as well as the realities of the border area where he grew up, A-Meng is proficient in . . . Mandarin, English, Burmese, and Dai. ... influenced by his father's lifelong work as a rubber farmer, A-Meng had developed a strong interest in rubber ... In order to maximize his family's profits ... he applied . . . to the Southern China Agricultural University to study rubber. After graduating in 2015, his father, already an old man, gave A-Meng all of his possessions, which consisted primarily of a 5 ha rubber plantation ... A-Meng, thanks to his own knowledge and ability, transformed all 5 ha rubber into an eco-rubber plantation with mixed herbs, orchids, and fruit and other cash crop trees which together made up an integrated development system of rubber, and began to generate great economic and ecological benefits.

In 2016, like his parents, A-Meng took the "in vogue" transnational path and married a friend and classmate from Myanmar. They had a son in 2018, and his wife tended to the family as a housewife. . [To] gain a different type of education ... when he was 7 years old they sent their son to Chiang Mai for study and to train as a Buddhist [novice] for two years. Their son graduated from university and began to work as an intern for the Greater Mekong Region Committee last year.

In 2017, A-Meng decided to go into business with his friends investing in a rubber processing factory. They soon discovered that rubber seeds were a major by-product of rubber processing, and established a biodiesel power station, which eventually got linked with the Greater Mekong Power Grid. Rubber seeds from the factory produced 5000 tons of biodiesel per year. The biodiesel power station qualified for a government low-carbon emissions development tax subsidy. In 2018, ecological legislation had improved immensely, resulting in the approval and implementation of an Ecological Protection Regulation in Xishuangbanna. In 2020, the prefecture government made the "14th five year plan" to achieve the Regulation's target that in ten years, one million $m u[66,667 \mathrm{ha}]$ of low-yielding rubber land will be improved into high-yielding rubber, and returning two million $m u$ rubber to forest, limiting rubber to an area of 3 million $m u$. A-Meng was involved in the rubber land transformation project as well. He bought the neighboring lowyielding rubber fields, increasing his holdings from 5 ha to 20 ha total.

A-Meng was awarded the title of a "modern new rubber farmer" and began to be regularly invited to train farmers of eco-rubber plantations in Myanmar and Laos ... He established a rubber cooperative, which began to conduct online trade, product processing and technological training. He soon joined as a provider for the Mekong International Rubber Company ... through which he could sell to anywhere in the world. Through years of economic development and gradual urbanization, agricultural and service industrial workers were increasingly hired from bordering areas in Laos and Myanmar. AMeng too hired 10 fixed-term labourers ...

Economic development suffered from a serious drought in 2024. It changed the government's development strategy to focus on ecological protection, and subsequently ecological factors were brought into mechanisms for assessing government officials' performance. In 2025, ecosystem rehabilitation was implemented on a large scale due to a central government driven Ecosystem Payment System. The drought meant that A-Meng could not help but move from Daluo to Jinghong ... from where he would take the high speed rail back and forth...

Drought also increased the cost of irrigation and reduced rubber yields significantly. A-Meng and his sister often debated the development of rubber. Two years younger, his sister had attended Yunnan University and graduated in 2021 with a doctorate in environmental protection. Her doctoral thesis had discussed rubber production with their hometown as the primary example, and explored issues of natural resource protection. After she graduated, she joined an environmental protection society ...

In 2025, through his wife's contacts, A-Meng leased a piece of land on contract from the Myanmar government for 50 years. On this land he planted 30 ha rubber, but five years later the Myanmar government established a new policy reclaiming that land ... This drastic change in policy left him just barely 15 ha, which he sold hastily at a loss of 100,000 USD. In addition, the next year brought a devastating hurricane, under which he lost nearly 3 ha of rubber, and the hurricane's winds destroyed the bridge to the rubber fields. Still worse, a severe drought this year has led to the loss of even more of his rubber crop.

Moreover, A-Meng considered changing ... after the economic crisis of China in 2025. At his wit's end, his sister reminded him that perhaps it was time for a change, and under her advice he planted 3 ha of dendrobium whose market price was high. He funded the transformation in production in part with his own money, and raised the rest through the International Rubber Company and the Xishuangbanna Government ... .

A-Meng and his sister also established a Rainforest Foundation, and donated 10,000,000 yuan as a loan for the ecological restoration of 
rubber plantations. This year's international symposium called for 7 countries to restore tropical rainforest, with the belief that they should find a management approach which provides both profit and environmental protection, with the hopes of ensuring a bright future for Xishuangbanna ...

Source: after Xishuangbanna Group 2 in Foran et al. 2013. Note: italicized text refers to inferred cross-workshop storyline element.

\section{DISCUSSION}

It is difficult enough to comprehend today's complexities, let alone imagine how they might unfold decades into the future. The technique presented here may help improve the specificity and authenticity of environmental scenario storylines. In this section we discuss how the technique responds to several methodological challenges introduced at the outset: critical and systematic inquiry, policy salience, and endogenous development. We also identify limitations of this technique as applied in the Mekong Futures workshops.

\section{Critical inquiry}

Critical inquiry raises several questions, beginning with how to specify a credible subset of futures for subsequent exploration. Our technique asks participants to nominate trends and critical uncertainties, then specify future outcomes and trajectories (Step 4). Inclusion of trends as well as critical uncertainties results in a scenario framework that consists of more than two or three uncertain drivers (Tables 1 and 2). A more elaborate framework can improve transparency if participants offer explicit assumptions about specific drivers. It can also direct participants to imagine how novelty emerges from path-dependency.

Although this "decision tree" approach allows a more elaborate specific scenario framework to be created, it entails a trade-off. All possible combinations of future outcome values cannot be practically explored, as they could if participants were following the "twin-axis" (scenario-cross) approach, which elaborates narratives that explore contrasting outcome values for a limited set of drivers (Jäger et al. 2007, SEI and CIFOR 2009). The decision tree approach requires experienced facilitation to help participants arriving at a plausible and interesting specific scenario framework (Henrichs et al. 2010).

A second set of questions has to do with depth of foresight, that is, how thorough and profound the elaboration of each future is. How can applications go beyond outcomes influenced by dominant or conventional beliefs and worldviews, which may be too restrictive when exploring futures? Participants readily wove economic and policy shocks and surprises of varying scale and magnitude into their narratives. The tendency to incorporate surprise was possibly enhanced by our use of turn-taking oral storytelling, which can be a performative and competitive activity. However, participants were less adept at incorporating multiple possible interactions between food, water, and energy (Box 1). We discuss two strategies to help improve critical inquiry.

\section{Refining strategy}

Various forms of knowledge can be added to draft storylines, so as to improve their plausibility, i.e., credibility, to audiences. Steps (5) and (7) in our technique provide examples of this approach. Box 1 shows how a chronological, characterbased narrative design can incorporate detailed statements, expanding dimensionality. Developing a detailed, agentoriented narrative improves authenticity: as details accumulate, the audience receives a more detailed pattern or image; elements that lack coherence or rest on questionable assumptions are relatively easy to identify compared with storylines in which the narrative remains incomplete in terms of plotline (what happens) or agency (how change occurs and by whom).

In Step (7) organizers extract cross-scale events from other Mekong small group narratives. These events are selected on the basis they potentially enable or inhibit putatively desired events in a given storyline (Appendix 1). In theory this technique could result in participants creating second-order stories that combine two or more contradicting scenario frameworks. In practice, however, we found that participants considered their original scenario framework, and the dynamics in their original storyline, to contextualize events incorporated from other stories. In other words, participants maintained coherence of their original scenario logic, and the imported enablers or inhibitors were processed as perturbations.

Other examples of a refining strategy to improve critical inquiry, as well as policy salience, include the following triangulation methods and techniques:

1. Before elaborating narratives, explore systemic relations qualitatively, using influence diagrams (SEI and CIFOR 2009), as well as more formal techniques, such as fuzzy cognitive mapping (Kok 2009), agent-based simulation (Bousquet et al. 2007, Smajgl 2010), and system dynamics modeling (Alcamo 2008).

2. Lengthen temporal scale. Our application used a time scale of approximately 50 years (20 retrospective, 30 prospective). A longer time scale, e.g. four centuries, might be more appropriate to explore fundamental sustainability challenges, but deserves historical expertise (cf. Costanza et al. 2007) in facilitating what becomes, assuming use of character-based technique, an extended multigenerational narrative. The Mekong narratives commonly included three generations (see Box 1). 
3. For a given specific scenario framework, generate additional, contrasting character-driven narratives. Also generate narrative/s at a higher level of social organization, e.g., with social factions or states as protagonists. Generating more than one narrative avoids the limitations of a narrative that focuses too narrowly on the career of a single protagonist, and helps capture heterogeneity. An approach that includes both micro- and macro-oriented stories allows the former to be contextualized, and the latter to be grounded.

\section{Challenge and reconstruct strategy}

A different triangulation approach, applied in the Mekong Futures project, was to challenge certain important causal beliefs elicited from participants (Smajgl et al. 2011). Using the seven-step technique presented here, participants developed qualitative narratives to a reasonably sophisticated level (Fig. 1, activity II), without using systems analysis techniques. The project then treated the narratives as repositories of implicit causal beliefs and vision statements. In this approach, critical inquiry is furthered when scientific insights are compared against participants' visions and causal beliefs (Fig. 1, activity III). In this strategy, models are not used to quantify all of the key dynamics in qualitative narratives (cf. Bousquet et al. 2007), but rather to challenge certain pivotal, recurring beliefs. For example, a belief that appears in mainstream discourse, detectable in several of the stories, is that large-scale irrigation development will reduce poverty (Molle et al. 2009). By contrast, the project's agentbased simulation, calibrated by household surveys in northeast Thailand, found that irrigation development could increase farm productivity and incomes, but not poverty, largely because of the unequal distribution of land.

The challenge and reconstruct strategy is risky in that it deliberately separates participants from development of simulation models. To the extent that participants are willing to accept novel or counterintuitive findings presented by a science team, their causal beliefs might change. The final activity of the Mekong Futures project offered a space for policy dialogue about possible alternative development investments (Fig. 1, activity IV). In short, a variety of triangulation methods exist that in principle allow scenario builders to go beyond storylines dominated by conventional beliefs and worldviews. More insight is needed on precise combinations and sequences of techniques to improve modelfacilitated actor learning.

\section{Policy salience}

By salience, we refer to the relevance of a particular knowledge discourse for current decision makers' needs. How can scenario approaches engage today's policy makers in discussion around challenging, uncertain, controversial future developments and response strategies (Patel et al. 2007, Volkery et al. 2008, SEI and CIFOR 2009)?

The Mekong Futures project did not directly test the salience of character-based narratives. Indirect evidence about salience comes from participant retention rates for five workshops the project scheduled for each setting. Retention rates ranged from 65-80\% dependent on setting, indicating support for the overall methodology. Asked how useful the project's overall series of workshops were (Fig. 1), participants reported increased systems understanding, as well as the value of shared visioning:

Sometimes . . . our river basin committees . . .
[allocated] water without thinking of any related
factors... that condition poverty of rural families.
We then see [through the workshops] that water is
not the single bullet to help reduce poverty... [The
workshops] brought together different departments,
different visions [and] their own background...
now they tend to be forming a common vision, that
was a very good [outcome] (Thailand participant,
interview 26 November 2012).

Of the 21 narratives produced in 6 settings, only 1 group of participants declined to produce a final character-based narrative. This group of older, senior Vietnamese officials initially produced a character-based narrative then abandoned it in favor of a statement of long-term strategic priorities. On the other hand, in our Laos setting, the head of the governmental host organization, a younger man, stated that the qualitative multistakeholder visioning process was critical to effective river basin planning, for all Lao PDR basins, and requested assistance developing a facilitator training curriculum.

Participants commented positively on use of character-based scenarios, and cross-scale exchanges: "It was very useful in getting people stimulated and engaged in thinking about the future they want, or want to avoid"(J. Dore, personal communication 4 April 2013).

"[T]elling a character-based story was quite new and interesting ... some of the participants [subsequently] applied similar story telling method to their research" (Su Yufang, personal communication 2 April 2013).

"[L]istening to stories from outside their areas/region made them understand better external factors that may influence the results of their decision on development or actions - thus they modified the stories to be more realistic" (C. Krittasudthacheewa, personal communication 2 April 2013).

We also received trenchant critique from participants, including comments on (1) the scientific credibility of scenario-building (S. Yufang, personal communication 2 April 2013); (2) the vital role of skilled facilitation and story 
writing (J. Xu, personal communication 4 April 2013); (3) occasional confusion about the role of narrative scenarios in a complex methodology (D. K. Nhan, personal communication 5 April 2013); and (4) interest in seeing the visions taken forward, beyond the life of the research project, in further analysis and communication (C. Krittasudthacheewa, personal communication 2 April 2013; J. Dore, personal communication 4 April 2013). Points (2) to (4) reflect our weaknesses in implementation and engagement; our response to point (1) appears under "Critical Inquiry" above.

In general salience can be problematic because decision makers may feel that obtaining longer term foresight is of lower priority than near-term support. For decision makers who acknowledge they need foresight, the narrative technique allows particular effects of policy drivers to be explored imaginatively, for example, time required to implement particular policy reforms, and changing social-ecological conditions (Box 1).

\section{Agency and endogenous development}

By endogenous development we mean purposive change that is negotiated at the "local" scale between a range of lower and higher level actors. In applications exploring local futures, an important methodological issue is how to explore agency plausibly, given the power of higher order forces (Wangel 2011). This is an important empirical question, but one that also involves how to conceptualize agency, particularly the collective action of weaker actors.

Through interviews and fieldwork, scenario organizers can get a better understanding of capacities for collective agency (Özkaynak and Rodríguez-Labajos 2010) implied by such visions. A preliminary content analysis of the Mekong stories found few explicit references to mechanisms of collective agency. Relevant processes include forming groups, narrating issues in ways helpful to mobilization, linking with external groups and networks, and mobilizing to make claims on more powerful actors (McAdam et al. 2001, Foran 2006).

In most stories collective agency remained underdeveloped. This is possibly a combined result of our suggestion for participants to create character-based narratives, which occasionally yielded heroic storylines, and the lack of familiarity participants, e.g., government officials representing national agencies, may have had with community-led development. We suggest that facilitators with governance expertise support participants to understand the importance of collective agency, exploring it in more detail.

\section{CONCLUSION}

Building qualitative scenario narratives is one way to explore complex futures in a participatory manner. Responding to a lack of explicated technique in the environmental scenario literature, we described a technique to create detailed qualitative storylines. Its most innovative feature is the combination of iterative, participatory storyline development based on reading of collated storylines from other places. The iterative, cross-locale approach allows participants to deepen cross-scale understanding. Participant-created narratives contain both causal and normative beliefs, making the technique particularly suited to dialogues on sustainable development. Narratives explore and express development visions, serving as a reference point for further sciencemediated dialogues. The technique's emphasis on ordinary language narrative offers a way to engage new participants, as well as for all participants to explore abstract concepts such as uncertain driving forces. Without professional writing assistance, participants created relatively complex dynamic storylines, in which agents respond to changing structures and in turn act on them. The strengths of participatory applications of this technique are also its limitations. The quality of discussion ultimately depends on facilitation skills, as well as on the knowledge and imagination that participants can offer in a group process. The technique currently works best in situations of parameter uncertainty, and is less reliable for exploring emergent driving processes. To improve participatory learning, more insight is needed on effective combinations of narrative and non-narrative techniques.

Responses to this article can be read online at: http://www.ecologyandsociety.org/issues/responses. php/5796

\section{Acknowledgments:}

This paper results from the Exploring Mekong Region Futures project, funded by the AusAID-CSIRO Research for Development Alliance. We received extremely helpful comments on the manuscript from three anonymous reviewers and Thomas Measham. We thank more than 200 people who participated in the scenario building workshops. For facilitation and event organization, we thank: Nguyen Thanh Binh, Angela Bush, Chanthanet Boualapa, Lilao Bouapao, John Dore, Hua Hong Hieu, Uraiwan Inmuong, Xu Jianchu, He Jun, Chayanis Krittasudhthacheewa, Souphasay Komany, Yanyong Inmuong, Guillaume Lacombe, Robert Mather, Dang Kieu Nhan, Someth Paradis, Ornuma Polpanich, Lan Pousavanh, Aura Salmivaara, Yan Samrith, Pech Sokhem, Phatcharee Srikuta, Thanakit Thuwasri, Hell Tony, Van Pham Dang Tri, Nguyen Hieu Trung, Vo Van Tuan, Nuchanart Vararakprapat, Lu Xing, Su Yufang, and Bai Zhihong.

\section{LITERATURE CITED}

Alcamo, J. 2001. Scenarios as tools for international environmental assessments. Environment Issue Report No 24. European Environment Agency, Copenhagen, Denmark. 
[online] URL: http://www.eea.europa.eu/publications/ environmental issue report 200124

Alcamo, J. 2008. Chapter six. The SAS approach: combining qualitative and quantitative knowledge in environmental scenarios. Pages 123-150 in J. Alcamo, editor. Environmental futures: the practice of environmental scenario analysis. Elsevier, Amsterdam, The Netherlands. http://dx.doi. org/10.1016/S1574-101X(08)00406-7

Bousquet, F., J.-C. Castella, G. Trébuil, C. Barnaud, S. Boissau, and S. P. Kam. 2007. Using multi-agent systems in a companion modelling approach for agroecosystem management in South-east Asia. Outlook on Agriculture 36:57-62. http://dx.doi.org/10.5367/000000007780223650

Chermack, T. J. 2004. Improving decision-making with scenario planning. Futures 36:295-309. http://dx.doi. org/10.1016/S0016-3287(03)00156-3

Costanza, R., L. J. Graumlich, and W. L. Steffen. 2007. Sustainability or collapse? An integrated history and future of people on earth. MIT Press in cooperation with Dahlem University Press, Cambridge, Massachusetts, USA.

Costanza, R., I. Kubiszewski, P. Paquet, J. King, S. Halimi, H. Sanguanngoi, N. L. Boch, R. Frankel, J. Ganaseni, A. Intralawan, and D. Morell. 2011. Planning approaches for water resources development in the Lower Mekong Basin. Portland State University, Mae Fah Luang University, Portland, Oregon, USA.

Da Costa, O., P. Warnke, C. Cagnin, and F. Scapolo. 2008. The impact of foresight on policy-making: insights from the FORLEARN mutual learning process. Technology Analysis \& Strategic Management 20:369-387. http://dx.doi. org/10.1080/09537320802000146

Evans, K., S. J. Velarde, R. P. Prieto, S. N. Rao, S. Sertzen, K. Davila, P. Cronkelton, and W. de Jong. 2006. Field guide to the future: four ways for communities to think ahead. E. Bennett and M. Zurek, editors. Center for International Forestry Research (CIFOR), ASB, World Agroforestry Centre, Nairobi, Kenya. [online] URL: http://www.asb.cgiar. org/PDFwebdocs/Evans-et-al-2006-Field-guide-to-the-future. pdf

Foran, T. 2006. Rivers of contention: Pak Mun Dam, electricity planning, and state-society relations in Thailand, 1932-2004. Dissertation, Division of Geography, Department of Geosciences, University of Sydney, Sydney, Australia. [online] URL: http://hdl.handle.net/2123/1984

Foran, T., and L. Lebel. 2007. Informed and fair: water and trade futures in the border regions of mainland Southeast Asia. Mekong Program on Water Environment and Resilience (MPOWER). Vientiane, Laos. [online] URL: http://www. mpowernetwork.org/Knowledge Bank/Key Reports/ Dialogue Reports/Informed_and_Fair.html
Foran, T., and L. Lebel. 2012. Using holistic scenarios to rewrite rural futures. Pages 199-216 in S. Lockie and T. G. Measham, editors. Risk and social theory in environmental management. CSIRO, Collingwood, Australia.

Foran, T., J. Ward, A. Leitch, X. Lu, and A. Smajgl. 2013. Exploring Mekong Region Futures. A compilation of scenarios. CSIRO Ecosystem Sciences, Canberra, Australia. [online] URL: http://www.csiro.au/ /media/CSIROau/Divisions/ CSIRO\%20Ecosystem\%20Sciences/Mekong-Futures-Reports/ Exploring\%20Mekong\%20Futures_Scenarios\%20technical\% 20report 2013 7\%20June.ashx

Gallopin, G., A. Hammond, P. Raskin, and R. Swart. 1997. Branch points: global scenarios and human choice. PoleStar Series Report No. 7, Global Scenarios Group, Stockholm Environment Institute, Stockholm, Sweden.

Henrichs, T., M. Zurek, B. Eickhout, K. Kok, C. RaudseppHearne, T. Ribeiro, D. van Vuuren, and A. Volkery. 2010. Scenario development and analysis for forward-looking ecosystem assessments. Pages 151-219 in N. Ash, H. Blanco, C. Brown, K. Garcia, T. Henrichs, N. Lucas, C. RaudseppHearne, R. D. Simpson, R. Scholes, T. P. Tomich, B. Vira, and M. Zurek, editors. Ecosystems and human well-being. A manual for assessment practitioners. Island Press, Washington, D.C., USA.

International Centre for Environmental Management (ICEM). 2010. MRC strategic environmental assessment of hydropower on the Mekong mainstream. Final Report. October 2010. ICEM, Hanoi, Vietnam.

International Monetary Fund (IMF). 2012. World economic outlook database. IMF, Washington, D.C., USA. [online] URL: http://www.imf.org/external/pubs/ft/weo/2012/01/weodata/ index.aspx

Jäger, J., D. S. Rothman, C. Anastasi, S. Kartha, and P. van Notten. 2007. Module 6. Scenario Development and analysis. In GEO resource book: a training manual on integrated environmental assessment and reporting. United Nations Environment Programme and International Institute for Sustainable Development, Winnipeg, Manitoba, Canada.

John, P. 1998. Analysing public policy. Pinter, London, UK.

Kahn, H., A. J. Wiener, and Hudson Institute. 1967. The year 2000: a framework for speculation on the next thirty-three years. McMillan, New York, New York, USA.

Kok, K. 2009. The potential of fuzzy cognitive maps for semiquantitative scenario development, with an example from Brazil. Global Environmental Change 19:122-133. http://dx. doi.org/10.1016/j.gloenvcha.2008.08.003

Kok, K., R. Biggs, and M. Zurek. 2007. Methods for developing multiscale participatory scenarios: insights from Southern Africa and Europe. Ecology and Society 13(1): 8. 
[online] URL: http://www.ecologyandsociety.org/vol12/iss1/ $\underline{\operatorname{art} 8 /}$

Lebel, L. 2006. Multi-level scenarios for exploring alternative futures for upper tributary watersheds in mainland Southeast Asia. Mountain Research and Development 26:263-273. http://dx.doi.org/10.1659/0276-4741(2006)26[263:MSFEAF] 2.0.CO;2

Lebel, L. and E. Bennett. 2008. Participation in building scenarios of regional development. Pages 207-222 in J. Norberg and C. S. Cumming, editors. Complexity theory for a sustainable future. Columbia University Press, New York, New York, USA.

Lebel, L., J. Dore, R. Daniel, and Y. S. Koma, editors. 2007. Democratizing water governance in the Mekong region. Mekong Press, Chiang Mai, Thailand.

Lichbach, M. I., and A. S. Zuckerman, editors. 1997. Comparative politics: rationality, culture, and structure. Cambridge University Press, Cambridge, UK.

McAdam, D., S. Tarrow, and C. Tilly. 2001. Dynamics of contention. Cambridge University Press, New York, New York, USA. http://dx.doi.org/10.1017/CBO9780511805431

Metzger, M. J., M. D. A. Rounsevell, H. A. R. M. Van den Heiligenberg, M. Pérez-Soba, and P. Soto Hardiman. 2010. How personal judgment influences scenario development: an example for future rural development in Europe. Ecology and Society 15(2): 5. [online] URL: http://www.ecologyandsociety. org/vol15/iss $2 / \operatorname{art} 5 /$

Molle, F., T. Foran, and M. Käkönen, editors. 2009. Contested waterscapes in the Mekong region: hydropower, governance and livelihoods. Earthscan, London, UK.

Özkaynak, B., and B. Rodríguez-Labajos. 2010. Multi-scale interaction in local scenario-building: a methodological framework. Futures 42:995-1006. http://dx.doi.org/10.1016/ j.futures.2010.08.022

Patel, M., K. Kok, and D. S. Rothman. 2007. Participatory scenario construction in land use analysis: an insight into the experiences created by stakeholder involvement in the Northern Mediterranean. Land Use Policy 24:546-561. http:// dx.doi.org/10.1016/j.landusepol.2006.02.005

Rothman, D., J. Agard, and J. Alcamo. 2007. The future today. Pages 395-454 in Global Environmental Outlook 4: Environment for Development. United Nations Environment Programme, Nairobi, Kenya.

Rounsevell, M. D. A., and M. J. Metzger. 2010. Developing qualitative scenario storylines for environmental change assessment. WIREs Climate Change 1:606-619. http://dx.doi. org/10.1002/wcc.63
Schwartz, P. 1991. The art of the long view: planning for the future in an uncertain world. Currency Books/Doubleday, New York, New York, USA.

Smajgl, A. 2010. Challenging beliefs through multi-level participatory modelling in Indonesia. Environmental Modelling \& Software 25:1470-1476. http://dx.doi. org/10.1016/j.envsoft.2010.04.008

Smajgl, A., T. Foran, J. Dore, S. Larson, and J. Ward. 2011. Visions, beliefs and transformation: methods for understanding cross-scale and trans-boundary dynamics in the wider Mekong region. CSIRO Ecosystem Sciences, Canberra, Australia. [online] URL: http://www.csiro.au/en/ Organisation-Structure/Divisions/Ecosystem-Sciences/MekongFutures-Methodology.aspx

Smajgl, A., and J. Ward, editors. 2013. The water-food-energy plexus in the Mekong region: assessing development strategies considering cross-sectoral and transboundary impacts. Springer, New York, New York, USA.

Stockholm Environment Institute (SEI) and Center for International Forestry Research (CIFOR). 2009. Multiplescale participatory scenarios: visions, policies, and pathways. Stockholm Environment Institute and CIFOR, Stockholm, Sweden.

Termeer, C. J. A. M., A. Dewulf, and M. van Lieshout. 2010. Disentangling scale approaches in governance research: comparing monocentric, multilevel, and adaptive governance. Ecology and Society 15(4): 29. [online] URL: http://www. ecologyandsociety.org/vol15/iss4/art29/main.html

van Asselt, M. B. A., and N. Rijkens-Klomp. 2002. A look in the mirror: reflection on participation in integrated assessment from a methodological perspective. Global Environmental Change 12:167-184. http://dx.doi.org/10.1016/S0959-3780 (02)00012-2

Van Berkel, D. B., S. Carvalho-Ribeiro, P. H. Verburg, and A. Lovett. 2011. Identifying assets and constraints for rural development with qualitative scenarios: a case study of Castro Laboreiro, Portugal. Landscape and Urban Planning 102:127-141. http://dx.doi.org/10.1016/j.landurbplan.2011.03.016

van Notten, P. W. F., J. Rotmans, M. B. A. van Asselt, and D. S. Rothman. 2003. An updated scenario typology. Futures 35:423-443. http://dx.doi.org/10.1016/S0016-3287(02)00090-3

Vervoort, J. M., K. Kok, P.-J. Beers, R. Van Lammeren, and R. Janssen. 2012a. Combining analytic and experiential communication in participatory scenario development. Landscape and Urban Planning 107:203-213. http://dx.doi. org/10.1016/j.landurbplan.2012.06.011 
Vervoort, J. M., L. Rutting, K. Kok, F. L. P. Hermans, T. Veldkamp, A. K. Bregt, and R. van Lammeren. $2012 b$. Exploring dimensions, scales, and cross-scale dynamics from the perspectives of change agents in social-ecological systems. Ecology and Society 17(4): 24. http://dx.doi.org/10.5751/ ES-05098-170424

Volkery, A., T. Ribeiro, T. Henrichs, and Y. Hoogeveen. 2008. Your vision or my model? Lessons from participatory land use scenario development on a European scale. Systemic Practice and Action Research 21:459-477. http://dx.doi. org/10.1007/s11213-008-9104-x

Wangel, J. 2011. Exploring social structures and agency in backcasting studies for sustainable development. Technological Forecasting and Social Change 78:872-882. http://dx.doi. org/10.1016/j.techfore.2011.03.007

Ward, J., T. Foran, A. Smajgl, L. Bouapao, S. Pech, and X. Lu. 2012. Mekong energy metabolism: connecting energy demand into the nexus of food-water-energy security. Pages 364-385in H. Moinuddin and J. Maclean, editors. International Conference on GMS 2020: balancing economic growth and environmental sustainability: focusing on foodwater-energy nexus. Asian Development Bank, Manila, Philippines. 
Appendix 1. Example of comparative table.

Xishuangbanna Story from Group Two (Story of A-Meng and his family)

Suggested other stories to read: Xishuangbanna 1 and 3; Thailand 1; Regional 1 and 3; Vietnam 2

\begin{tabular}{lll}
\hline \multicolumn{1}{c}{ This Story $(2011-2041)$} & \multicolumn{2}{l}{ Relevant events in Other Stories } \\
\hline Desirable Elements & Undesirable & $\begin{array}{l}\text { Potential } \\
\text { Inhibitors }\end{array}$ \\
& & Potential Enablers \\
\hline
\end{tabular}

Financial security for small rubber farmers

New strains of rubber allow great

improvements in productivity; including

highly drought resistant and GMO varieties

Efficient technology: Drip irrigation for 5 ha

of rubber used to adapt to drought

Rubber cooperative helps farmers with a

rubber cooperative, online trade, processing

and technological training

Cross-border migration for education and work Temporary employees from outside

Xishuangbanna need to be hired

High speed rail allows long distance travel for work
Shortage in local labour

Mekong Region

Council (see

Regional 1)

Thailand 2 also supports high speed

rail

\begin{tabular}{lll}
\hline & $\begin{array}{l}\text { Climate change leads to } \\
\text { drought and water } \\
\text { shortages for agriculture } \\
\text { Other natural disasters: } \\
\text { hurricanes }\end{array}$ & $\begin{array}{c}\text { Water storage } \\
\text { infrastructure }\end{array}$ \\
& $\begin{array}{l}\text { Instability in government } \\
\text { policy (in this case } \\
\text { Myanmar) regarding } \\
\text { access to land generates } \\
\text { risk to investors }\end{array}$ & Integrated small \\
& & $\begin{array}{l}\text { holder farming model } \\
\text { (Thailand 1) }\end{array}$ \\
\hline $\begin{array}{l}\text { Diversification away from rubber (flowers; } \\
\text { fruit) }\end{array}$ & & $\begin{array}{l}\text { Carbon finance } \\
\text { (Regional 1, } \\
\text { A management approach which provides both } \\
\text { profit and environmental protection }\end{array}$ \\
$\begin{array}{l}\text { Financing becomes available for ecological } \\
\text { restoration of rubber plantations (through } \\
\text { taxes and loans) in Yunnan and Myanmar }\end{array}$ & & Regional 3)
\end{tabular}

